\title{
About issue no. 46
}

\section{(2) OpenEdition \\ 12 Journals}

Electronic version

URL: http://journals.openedition.org/ries/798

DOI: $10.4000 /$ ries.798

ISSN: 2261-4265

\section{Publisher}

Centre international d'études pédagogiques

\section{Printed version}

Date of publication: 1 December 2007

ISBN: 978-2-8542-0574-9

ISSN: $1254-4590$

\section{Electronic reference}

"About issue no. 46 », Revue internationale d'éducation de Sèvres [Online], 46 | décembre 2007, Online since 01 July 2011, connection on 02 May 2019. URL : http://journals.openedition.org/ries/798 ; DOI : $10.4000 /$ ries. 798

This text was automatically generated on 2 May 2019.

(c) Tous droits réservés 


\section{About issue no. 46}

1 More democratic societies, reinforced economic development, climbing up the social ladder made easier, reduction of school and social inequalities: Since the seventies, countless are the hopes embodied by the school system that have been thwarted or dashed. The massification of the access to school has not been followed by the expected changes in quality, as multiple international benchmarks and surveys have kept showing. Thus, the structural changes which have hit the work market and the depreciation of diplomas have both contributed to tarnishing the image of schools.

2 This diagnosis has been the stepping stone of educational policies led on a global scale which have rested on major reforms and on the promotion of innovations. Today, this cycle of voluntarist reforms seems to be coming to an end and the very notions of reform and innovation have undergone a strong erosion.

3 Yet, changes can be seen at work on different levels, be it local, national or supranational. Can comparative perspective allow to highlight the evolutions which tend to modify the general landscape skteched by educational systems? That is the basic premise of the present issue of the Revue internationale d'éducation de Sèvres, which collects the contributions of experts from different countries: France, Belgium, Brazil, Canada, Spain, Portugal and the United-Kingdom (Scotland).

4 Several contributors point out the lesser part played by States and the emergence of new managing modes which lead to hybrid and complex adjustments between the various levels of actions and decisions.

Between the increasingly mercantilist approach of education and the rise of local initiatives, several contributions advocate school diversity. 